\author{
Ludmila DULEBOVÁ ${ }^{1}$ \\ Branislav DULEBÁ ${ }^{2}$ \\ Emil SPIŠÁK ${ }^{3}$
}

\title{
ANALYSIS OF SOME ASPECTS OF FINE BLANKING PROCESS
}

\begin{abstract}
Blanking is one of the advanced technologies of processing materials and manufacturing products. Simple cutting is affected by the uneven action of plastic deformation. This makes the cut surface irregular. Blanking methods have been improved and new technologies in the process of blanking have been developed. Using these technologies we easier achieve higher geometric precision and surface quality. One of these technologies is fine-blanking. The aim this of study was to investigate the mechanical properties of the material and verify the suitability of the material for the production of parts made by fine blanking and analyze the failure of ejector tool. Based on the tests performed we can conclude that material DN-C45 (12045) is not suitable for the production components made by fine blanking technology. For production of parts, we recommend to use the material C45 in modification GKZ-EW - soft annealing, fine cold rolled with globular pearlite, tensile strength $480 \mathrm{MPa}$, yield strength of $290 \mathrm{MPa}$ and hardness maximum $150 \mathrm{HB}$. Based on documented microscopic breaches at ejector in etching state, we see that oxidation occurs at the point at the breach. In the present case for the assessment of cracks on the ejector, it is necessary to consider whether the thermal process was adhered.
\end{abstract}

Keywords: steel metal, fine blanking, quality of cutting surface

\section{Introduction}

Engineering production of parts constantly puts higher demands on the quality and reduces labor intensity in production. In a competitive environment only production with the lowest cost can achieve improvement, because they directly affect the profitability and profit. Manufacturers, therefore, invest in those technologies that are able to provide high productivity and quality of com-

\footnotetext{
${ }^{1}$ Autor do korespondencji/corresponding author: Ludmila Dulebová, Technical University in Košice, Mäsiarska 74, 04001 Košice, Slovakia, tel.: +421 556023502, e-mail: ludmila.dulebova@tuke.sk

2 Branislav Dulebá, Technical University in Košice, Mäsiarska 74, 04001 Košice, Slovakia, e-mail: branislav.duleba@tuke.sk

${ }^{3}$ Emil Spišák, Technical University in Košice, Mäsiarska 74, 04001 Košice, Slovakia, e-mail: emil.spisak@tuke.sk
} 
ponents. Blanking is one of the basic processes in sheet metal forming. Blanking is a constrained shearing operation that involves elastic deflection, plastic deformation and fracture of the work material. In the blanking process, some factors such as the punch-die clearance, the tool geometry and the mechanical properties of the materials influence the quality of the cross-section and the dimension precision. It is necessary to study the fracture of the metal and crack propagation to select rational process factors. In engineering practice, the shape of the product, near the cut edge, is by far the most important property. Shearing is one of the advanced technologies of processing materials and manufacturing products. Simple shearing is affected by the uneven action of plastic deformation. This makes the cut surface irregular. Shearing methods have been improved and new technologies in the process of shearing have been developed. Using these technologies we can easier achieve higher geometric precision and surface quality. One of these technologies is fine blanking [1-5].

In conventional metal stamping a 2-part punch and die set is used (Fig. 1). Fine blanking adds two more elements: a clamping or "stinger" plate to prevent die roll-off and a counter punch to control deformation as the punch pushes through the plate. Thus, the part is smoothly removed from the strip. The fine blanking process resembles an extrusion process rather than the shearing process of conventional stamping. This results in a part with superior flatness, smooth edges, less roll-off and tighter form tolerances. The improved tolerance control results from die to punch clearances of $1 / 5$ or less than that of conventional stamping [2,6]. Fine blanking is a specialized type of blanking in which the blank is sheared from the sheet stock by applying 3 separate forces - blanking force, holding force and counterforce (Fig. 2). This technique produces a part with better flatness, a smoother edge with minimal burrs, and tolerances as tight as $\pm 0.001 \mathrm{~mm}$. As a result, high quality parts can be blanked, so that they do not require any secondary operations. However, the additional equipment and tooling does add to the initial cost and makes fine blanking better suited to high volume production. The fine blanking has been used in automotive industry such as door locks, gear boxes, reclining seat adjusters etc. Furthermore, the fine blanking can also be applied to electronic and electrical industry [7].

Most of the equipment and setup for fine blanking is similar to conventional blanking. The sheet stock is still placed over a blanking die inside a hydraulic press and a blanking punch will impact the sheet to remove the blank. As mentioned above, this is done by the application of 3 forces. The first is a downward holding force applied to the top of the sheet. A clamping system holds a guide plate tightly against the sheet and is held in place with an impingement ring, sometimes called a stinger that surrounds the perimeter of the blanking location $[6,7]$. The second force is applied underneath the sheet, directly opposite the punch, by a "cushion". This cushion provides a counter force during the blanking process and later ejects the blank. These two forces reduce bending of the sheet and improve the flatness of the blank. The final force is 
provided by the blanking punch impacting the sheet and shearing the blank into the die opening. In fine blanking, the clearance between the punch and the die is smaller and the blanking is performed at slower speeds. As a result, instead of the material fracturing to free the blank, the blank flows and is extruded from the sheet, providing a smoother edge. To manufacture parts in fine blanking quality, the following conditions have to be met: press, tool and material.

\section{CONVENTIONAL STAMPING}
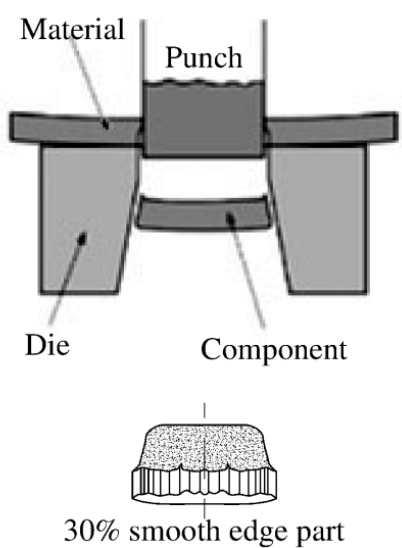

FINE BLANKING
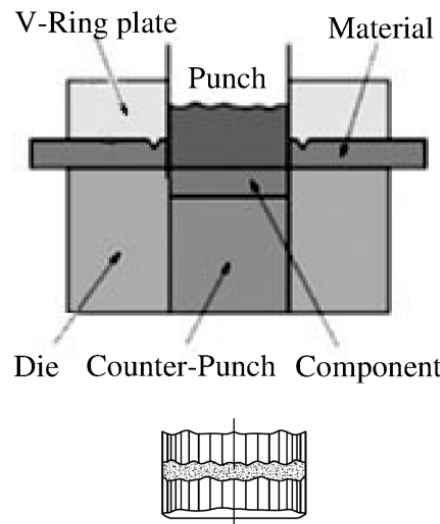

$75 \%-100 \%$ smooth edge part

Fig. 1. Comparison of conventional stamping and fine blanking processes

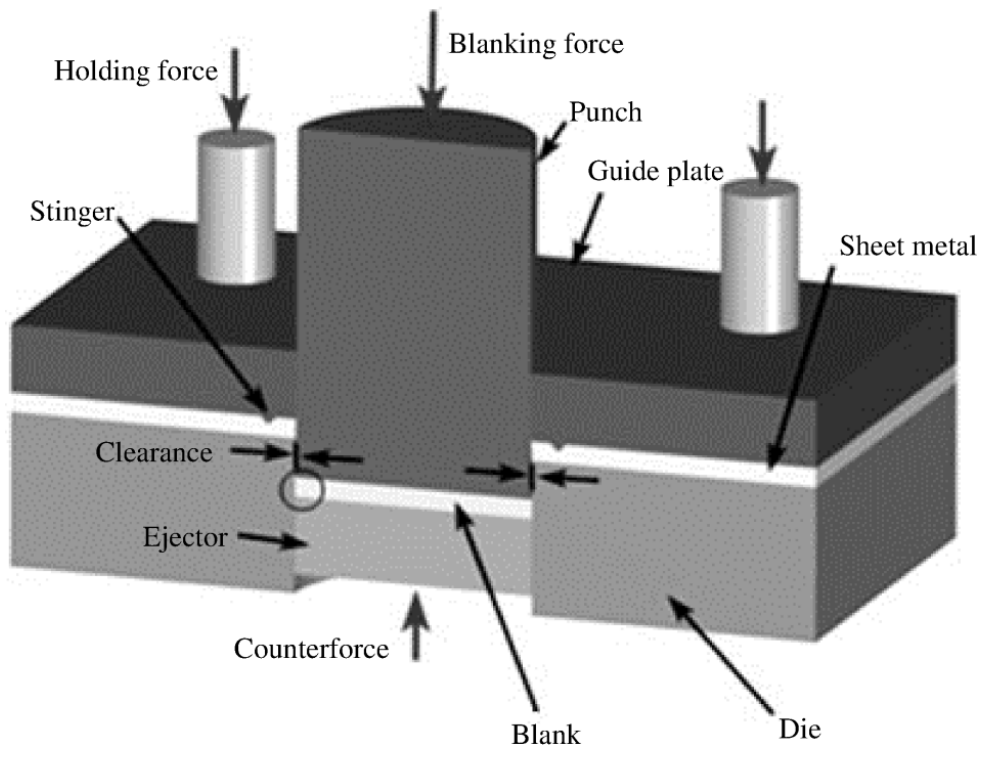

Fig. 2. Scheme of fine blanking equipment with forces acting 
For fine blanking technology are suitable materials, respectively steels with sufficient cold forming property and minimum yield strength. Ideal for fine blanking are low carbon steels and low-alloy steels with low content of alloys and value of yield strength under $600 \mathrm{MPa}[8,9]$. The decisive factor for the suitability of the material is its structure, which is affected by the content of carbon and alloying elements present and previous thermal processing. The raw material for fine blanked components is primarily rolled metal coils, although extruded and rolled strips are also used. In some cases non-metallic materials are fine blanked. Because fine blanking is as much an extrusion process as a stamping process, the consistent flowing of material into the die cavity is critical. For this reason soft materials and materials with fine grain structure are preferred. When an application requires a hardened component, heat treatable alloys are used. Types of steel suitable for fine blanking technology can be divided into four groups, which are listed in Table 1 [8]. For the fine blanking it is necessary to use material with uniform: chemical composition, structure, dimensional accuracy, mechanical properties. it The shape of the fragile components (cementite, pearlite etc.) in the material structure is also important for fine blanking. The fragile components have to be in globular shape to achieve cutting with a smooth shear surface.

The aim of this paper is to assess the suitability of the material DN-C45 for fine blanking and/or to propose a different material for the manufacture of the product. When using blanked DN-C45 material in as receive condition failure of ejector tool occurred and contribution examines the infringement of ejector pins for the production of selected parts by fine blanking. This contribution was prepared in collaboration with company that produces precise sheet-metal marts for automotive industry by fine blanking.

Table 1. Materials used for fine blanking technology

\begin{tabular}{|c|l|c|c|c|c|}
\hline $\begin{array}{c}\text { Group } \\
\text { of steels }\end{array}$ & \multicolumn{1}{|c|}{ Material } & $\begin{array}{c}\mathbf{C} \\
{[\mathbf{\%}]}\end{array}$ & $\begin{array}{c}\mathbf{C r} \\
{[\mathbf{\%}]}\end{array}$ & $\begin{array}{c}\mathbf{M o} \\
{[\%]}\end{array}$ & $\begin{array}{c}\mathbf{N i} \\
{[\%]}\end{array}$ \\
\hline 1 & Low carbon steel & $\max 0.1$ & - & - & - \\
\hline 2 & Carbon steel - non alloy & $0.12 \div 1.00$ & - & - & - \\
\hline 3 & Alloyed steels & $0.15 \div 0.20$ & $\max 2.00$ & $\max 0.30$ & $\max 2.00$ \\
\hline 4 & Stainless steel & $\max 0.15$ & $\max 18.00$ & - & $\max 18.00$ \\
\hline
\end{tabular}

\section{Experimental procedure}

Material symbol DN-C45 (STN 12045) with a sheet thickness of $3 \mathrm{~mm}$, delivered in roll form was used for testing. It is structural steel and is used to produce components statically and dynamically loaded. In this particular case, the material is used for the production of parts with complicated geometry (Fig. 
3a) by fine blanking technology. In the production practice at different stage of fine blanking process, fracture occurs at the ejectors (Fig. 3b) used as the counterpressure tool. The ejector was made from material 1.2379 (X153CrMoV12 according to EN ISO 4957), hardened to 59 HRC. In our work it was necessary to determine the mechanical properties and structure of the blanked material to determine its punchability as well as to document the reason of failure of ejector tool used for fine blanking.

a)

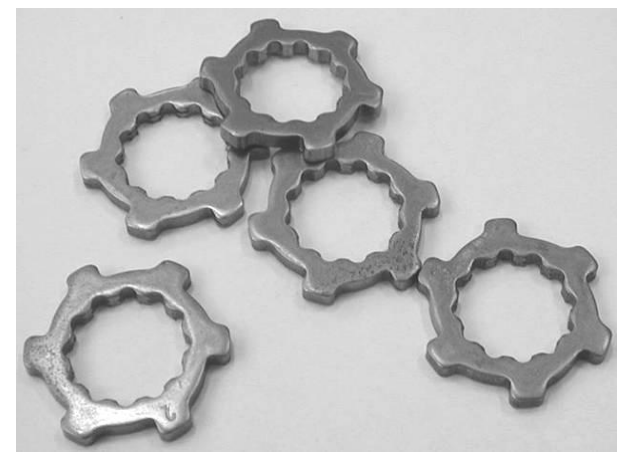

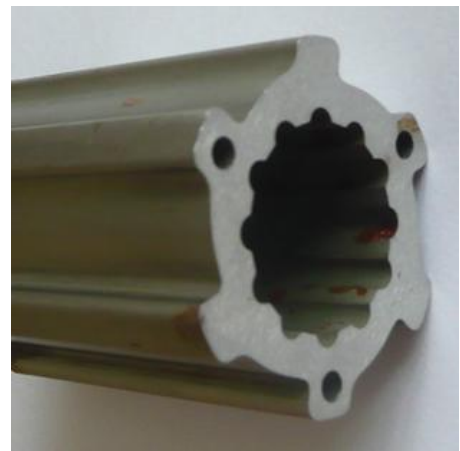

Fig. 3. Parts manufactured by fine blanking (a) and view of ejector (b)

The uniaxial tensile test (to determine mechanical properties of the material), Brinell hardness test (to determine effect of heat treatment) and structure optical observations were chosen for the evaluation of material suitability for fine blanking. The uniaxial test was performed according to STN EN 10002-1 on the test machine TIRA-test 2300. The test machine has a certificate of verification for testing the strength of metals and plastics. Brinell hardness test was performed on the hardness tester HPO 250 according to EN ISO 6506-1. Since mechanical characteristics essentially depend on the chemical composition of the material and its structure, the structure of the material was examined on the microscope OLYMPUS. For microscopic analysis sampling was made at the area of crack and metallographic grinding was performed. The sample was etched to induce the structure with $2 \%$ Nital.

\section{Results and discussion}

The results of uniaxial test and Brinell hardness test performed when using blanked sheet in as receive conditions are as follows:

- yield stress - $347 \mathrm{MPa}$,

- ultimate strength - $509 \mathrm{MPa}$,

- total elongation $-30.9 \%$,

- strain hardening exponent -0.193,

- hardness HB 62.5 - 146. 
The microstructure analysis of the blanked material, after etching on the cross-section, has shown fine globular pearlite, disturbances in the rolling direction, various inclusions, and bubbles (Fig. 4). Defects are oriented in the rolling direction - bubbles, inclusions were observed in the whole observed sample surface. Based on the tests above, their results and performed study of microstructure of the material, we can conclude that material DN-C45 is not suitable for the production components made by fine blanking technology. Because of that thermal treatment was applied to blanked sheet. After annealing the basic mechanical parameters were as follows:

- yield stress - $290 \mathrm{MPa}$,

- ultimate strength $-480 \mathrm{MPa}$,

- plastic anisotropy ratio - $0.997 \%$.

It means that the material, with modified symbol GKZ-EW, becomes more plastic and isotropic. Annealed steel sheet does not have metallurgical defects, i.e. cluster of non-metallic impurities, cracks, segregation and other defects.

a)

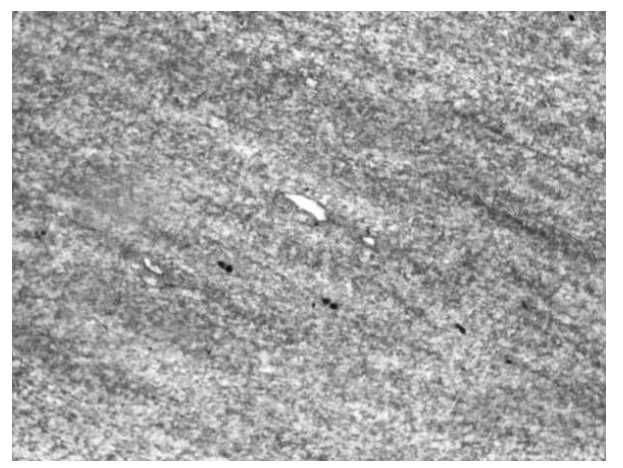

b)

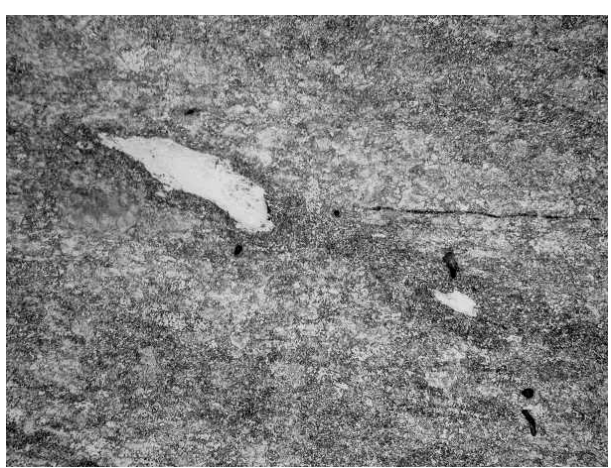

Fig. 4. Structure of material with bubbles and inclusions - magnification 100x (a) and 200x (b)

Microscopic observation of ejector after failure has shown that it was cracked in two places symmetrically near labels 1 and 3 (Fig. 5) and cracks were all over the cross section. Additional observation of the etched ejector surface at different stage of fine blanking process realization demonstrates that the initiation of material cracking takes place at inner wall edge (Fig. 6) and the propagate across the whole ejector wall thickness (Fig. 7). Probably unusual ejector surface topography could be a reason of cracks initiation, additionally stimulated by dynamic loading of cutting tool. 

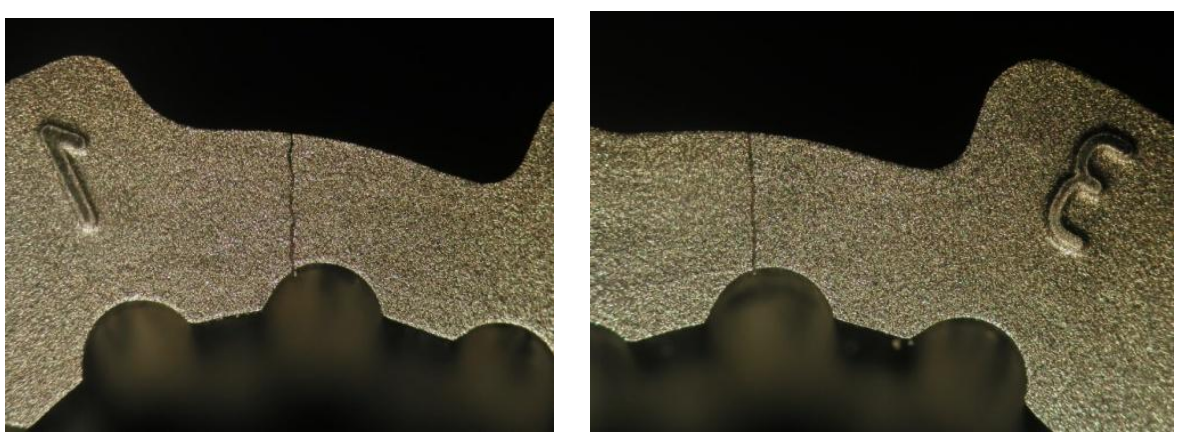

Fig. 5. Cracks observed at ejector tool near labels 1and 3
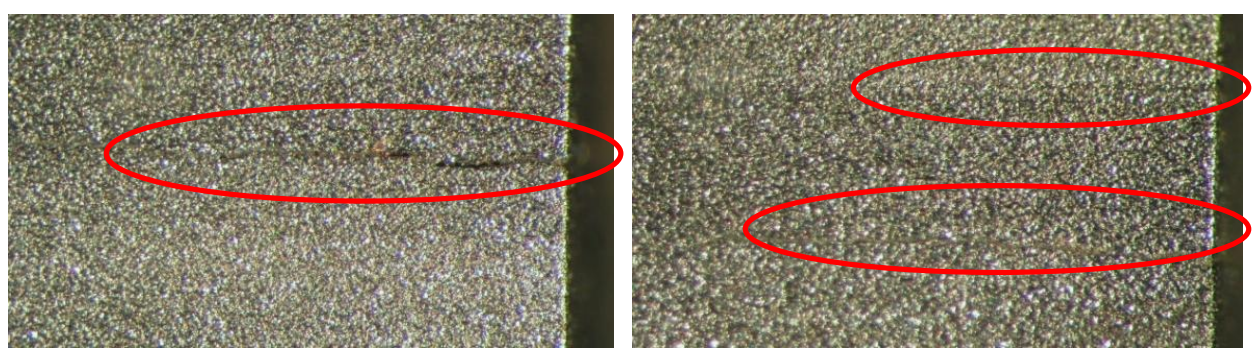

Fig. 6. Cracks initiation at ejector inner wall edge
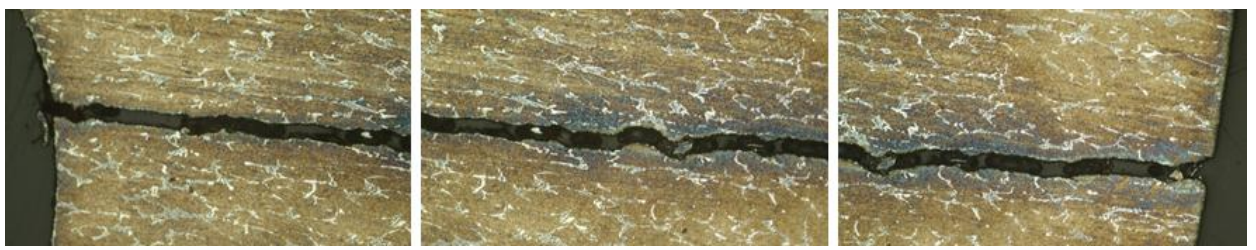

Fig. 7. Progress of cracks across the ejector wall thickness

\section{Conclusions}

The aim of study was to investigate the mechanical properties of the material and to verify the suitability of the material for the production of parts made by fine blanking and analyze the reason of ejector failure. Based on the tests presented above, we can conclude that material DN-C45 is not suitable for the production components made by fine blanking technology. For production of analyzed parts, we recommend to use the material $\mathrm{C} 45$ after modification by soft annealing. Special attention should be also paid to blanking tool production, i.e. material treatment and surface topography configuration. 


\section{References}

[1] Lange K.: Handbook of metal forming, McGraw-Hill Book Company, New York 1985.

[2] Kim Y.J., Kawk T.S., Bae W.B.: Finite element analysis on effect of die clearance on shear planes in fine blanking, J. Mat. Proc. Technol., 130-131 (2002), 462-468.

[3] Kwak T.S., Kim Y.J., Seo M.K., Bae W.B.: The effect of V-ring indenter on the sheared surface in the fine-blanking process of pawl, J. Mat. Proc. Technol., 143-144 (2003), 656-661.

[4] Frącz W., Kut S., Mucha J., Stachowicz F.: Experimental investigation of blanking process using TiN coated tool materials, Kovarenstvi, 33 (2008), 124-126.

[5] Frącz W., Kut S., Stachowicz F.: Experimental and numerical investigation of steel sheet blanking with pre-bending, Kovarenstvi, 33 (2008), 121-123.

[6] Dvořák M., Gajdoš F., Novotný K.: Technologie tváření: plošné a objemové tváření, CERM, Brno 2007.

[7] Novotný J., Langer Z.: Střihání a další spůsoby dělení kovových materiálů, SNTL, Praha 1980.

[8] Forejt M., Píška M.: Teorie obrábění, tváření a nástroje, CERM, Brno 2006.

[9] Greškovič F., Lachvač J., Hrivňak A., Spišak E.: Evaluation of cutting of steel sheets, Sci. Bul. Rzeszów Univ. Technol., 197 (2000), 109-114.

\section{Acknowledgements}

This paper is the result of the project implementation: Center for research of control of technical, environmental and human risks for permanent development of production and products in mechanical engineering (ITMS: 26220120060) supported by the Research \&Development Operational Program funded by the ERDF and VEGA No. 1/0369/11.

\section{ANALIZA WYBRANYCH ASPEKTÓW WYKRAWANIA DOKLADNEGO}

\section{Streszcenie}

Wykrawanie jest jedną z zaawansowanych technologii obróbki materiałów i wytwarzania elementów. Cięcie jest spowodowane nierównomiernym oddziaływaniem odkształcenia plastycznego, co skutkuje nierównomiernością powierzchni przecięcia. Metody wykrawania zostały ulepszone, co spowodowało rozwój nowych metod cięcia. Korzystając z tych technologii, można łatwiej osiągać dokładność geometryczną i jakość powierzchni przecięcia. Jedną z tych metod jest wykrawanie dokładne. Celem artykułu jest badanie właściwości mechanicznych materiału i sprawdzenie jego zdolności w produkcji elementów wykonanych przez dokładne wykrawanie oraz analiza zniszczenia wypychacza. Na podstawie przeprowadzonych badań można stwierdzić, że materiał DN-C45 (12045) nie nadaje sie do produkcji elementów wytwarzanych metodą wykrawania dokładnego. Do produkcji części zaleca się stosowanie materiału C45 zmodyfikowanego GKZ-EW - wyżarzaniem zmiękczającym, walcowanego na zimno i zawierającego perlit kulisty, o wytrzymałości na rozciaganie $480 \mathrm{MPa}$, granicy plastyczności $290 \mathrm{MPa}$ i twardości maksymalnej $150 \mathrm{HB}$. Na podstawie udokumentowanych mikroskopijnych wyrw 
w wyrzutniku poddanym trawieniu zaobserwowano, że w miejscu wyrw następuje utlenianie. W tym przypadku do oceny pęknięć wyrzutnika konieczne jest sprawdzenie, czy proces obróbki cieplnej został prawidłowo wykonany.

Słowa kluczowe: blacha, wykrawanie dokładne, jakość powierzchni przecięcia

DOI:10.7862/rm.2013.11

Otrzymano/received: 22.05 .2013

Zaakceptowano/accepted: 25.06 .2013 